\title{
DYSJUNKTYWIZM I NATURA PERCEPCYJNEJ RELACJI
}

Słowa kluczowe: dysjunktywizm, alternatywizm, relacja przyczynowa, relacja współkonstytuowania, percepcja, halucynacja, uzasadnienie epistemiczne Keywords: alternative-denialism, disjunctivism, causal relation, co-constitutive relation, perception, hallucination, epistemic justification

Dysjunktywizm $^{1}$ to teza broniona w różnych filozoficznych kontekstach ze względu na różne motywacje i z różnymi konsekwencjami. Niejednokrotnie

* Paweł J. Zięba - magister filozofii, magister historii, doktorant w Zakładzie Kognitywistyki Instytutu Filozofii Uniwersytetu Jagiellońskiego. Przygotowuje rozprawę doktorską Experiential Pluralism in Epistemology and Philosophy of Perception.

Address for correspondence: Paweł Zięba, Instytut Filozofii, ul. Grodzka 52, 31-044 Kraków. E-mail: pawelek.zieba@uj.edu.pl.

1 Artykuł dotyczy twierdzenia znanego w anglojęzycznej literaturze filozoficznej pod nazwą disjunctivism. Dosłowne thumaczenie tej nazwy na język polski to ,alternatywizm". W innym artykule pokazuję, że angielska nazwa jest niepoprawna, ponieważ nie odzwierciedla prawidłowo logicznej struktury określanej przez nią tezy. Tradycyjna nazwa wiąże się z przekonaniem, że omawiane twierdzenie nakazuje analizować każde doświadczenie zmysłowe przez pryzmat alternatywy rozłącznej. Niech $e$ będzie doświadczeniem, $\mathrm{P}$ - percepcją, I - iluzją, a $\mathrm{H}$ - halucynacją. Alternatywa rozłączna o postaci: „(e jest $\mathrm{P})$ lub (e jest $\mathrm{I})$ lub $(e$ jest $\mathrm{H})$ ” jest fałszywa wtedy, gdy wszystkie człony są fałszywe, lub wtedy, gdy więcej niż jeden człon jest prawdziwy. Wobec tego spójnik alternatywy rozłącznej zobowiązuje do zamkniętej klasyfikacji doświadczeń, mówiącej, że $e$ może być albo P, albo I, albo $\mathrm{H}$, ale nie może być niczym innym. Ale skąd wiadomo, że $e$ nie może być niczym innym? Być może istnieje jeszcze jakaś inna kategoria X, która 
zwracano już uwagę, że mylenie ze sobą poszczególnych aplikacji tego twierdzenia jest przyczyną wielu nieporozumień (Conduct, 2010, s. 203; Haddock, MacPherson, 2008, s. 1). Wobec tego zasadne jest postawienie pytania o wspólny dla tych wszystkich teorii mianownik, który pozwala określać je tą samą nazwą. Znalezienie odpowiedzi na to pytanie jest o tyle trudne, że wyróżnienie takiego wspólnego elementu nie może się odbyć kosztem zniekształcenia którejkolwiek z zawierających go teorii (Soteriou, 2010a, s. 223).

Kolebkę dysjunktywizmu stanowi pogranicze filozofii percepcji i epistemologii. Później twierdzenie to zostało zaaplikowane także w innych kontekstach, czego efektem są dysjunktywizm w kwestii introspekcji oraz dysjunktywizm w filozofii działania. Koncepcje te przejmują od oryginalnego dysjunktywizmu jedynie strukturę logiczną, wykorzystując ją do rozwiązania odmiennych problemów (Brogaard, 2011, s. 25-29). Pomijam je tutaj z uwagi na brak miejsca i ograniczam się do omówienia kilku reprezentatywnych przykładów ,oryginalnego” (tj. metafizycznego i epistemologicznego) dysjunktywizmu.

Nie ulega wątpliwości, że różne wersje dysjunktywizmu metafizycznego i dysjunktywizmu epistemologicznego łączy ze sobą zarówno wspomniana logiczna struktura, jak i ogólny kontekst, w którym koncepcje te są formułowane. Znacznie trudniej udzielić jednoznacznej odpowiedzi na pytanie o to, czy za wspólny mianownik pomiędzy ,oryginalnymi” dysjunktywizmami może być również uznany jakiś specyficzny, ściśle określony pogląd na naturę percepcyjnej relacji. Nie jest to problem błahy, ponieważ dokładne jego zbadanie pozwala rzucić światło nie tylko na podobieństwa i różnice pomiędzy poszczególnymi wersjami dysjunktywizmu, ale także na ich argumentacyjną efektywność i podatność na zarzuty.

Niniejszy artykuł ma charakter przede wszystkim przeglądowy, aczkolwiek w kilku miejscach otwarcie polemizuję z autorami innych podobnego typu tekstów. Z analizy kilku wybranych (lecz reprezentatywnych) wersji

nie jest ani $\mathrm{P}$, ani I, ani $\mathrm{H}$, i to do niej należy e. Czy twierdzenie znane jako disjunctivism w ogóle dotyczy doświadczeń typu X?

Niniejszy artykuł pokazuje, że twierdzenie to stwierdza jedynie, że P i H są fundamentalnie różne (status I bywa tu określany na różne sposoby), wobec czego tylko jeden człon tej formuły może być prawdziwy. Tę myśl lepiej oddaje spójnik dysjunkcji: ,e nie mogłoby być i P, i H" (fraza ta jest negacją konkluzji argumentu z halucynacji). Dlatego posługuję się nazwą „dysjunktywizm” (por. Zięba, b.d.w.). 
dysjunktywizmu wyciągam dwa wnioski: (1) dysjunktywiści nie są zgodni odnośnie do natury percepcyjnej relacji, a w związku z tym możliwość odrzucenia wszystkich „oryginalnych” dysjunktywizmów za pomocą jednego zarzutu należy uznać za wysoce wątpliwą; (2) wbrew temu, co sugeruje jego angielska nazwa, dysjunktywizm można poprawnie przedstawić bez posługiwania się funktorem alternatywy rozłącznej. Ten drugi wniosek nabiera znaczenia dopiero w powiązaniu z innym moim artykułem (Zięba, b.d.w.), dla którego niniejszy tekst stanowi uzupełnienie.

\section{W poszukiwaniu istoty dysjunktywizmu}

W stosownym haśle The Stanford Encyclopedia of Philosophy czytamy, że minimalnym zobowiązaniem dysjunktywizmu w filozofii percepcji (zwanego także metafizycznym) jest teza, w myśl której percepcje różnią się mentalnie od halucynacji pod pewnym istotnym względem, tzn. istnieją pewne mentalne własności, które przysługują percepcjom, ale nie przysługują halucynacjom (Soteriou, 2010b).

Wystarczy kilka drobnych modyfikacji, aby skonstruować ogólniejsze minimalne założenie, które będzie obowiązywało także dysjunktywizm epistemologiczny: percepcje i halucynacje różnią się z uwagi na posiadanie pewnych istotnych własności, nawet jeśli doświadczenia te mogą być subiektywnie nieodróżnialne. Należy podkreślić, że postulowana tu różnica musi zachodzić nawet wtedy, gdy percepcja i halucynacja są niemożliwe do odróżnienia z punktu widzenia doświadczającego ich podmiotu, mocą samej tylko refleksji (w przeciwnym razie stwierdzanie takiej różnicy byłoby trywialne). Przykładem rozważanej w tym kontekście pary doświadczeń będzie doświadczenie podmiotu $\mathrm{S}$ oraz odpowiadające mu doświadczenie kontrfaktycznego duplikatu S, który jest mózgiem w naczyniu².

To, jakie dokładnie własności odróżniają percepcje od halucynacji, zależy już od konkretnej teorii. Najczęściej wskazuje się tu na własności fenomenalne, intencjonalne lub epistemiczne. Ta sama myśl bywa wyrażana poprzez stwierdzenie, że percepcje i halucynacje nie są doświadczeniami

2 Sens omawianej tu nieodróżnialności w szczegółowy, a równocześnie jasny i zrozumiały sposób wyłożył M. Thau w swojej analizie polemiki J.L. Austina z A.J. Ayerem (zob. Thau, 2004, s. 214-215). 
tego samego fundamentalnego rodzaju, o przynależności do którego decyduje posiadanie takich lub innych własności (Soteriou, 2010b).

Można to rozumieć na dwa sposoby. Alex Byrne i Heather Logue piszą, że na gruncie dysjunktywizmu percepcje i halucynacje nie mają wspólnego „mentalnego rdzenia”, ergo nie istnieje wystarczająco specyficzny rodzaj stanów mentalnych, do którego percepcje i halucynacje wspólnie by należały (Byrne, Logue, 2009, s. IX). Byrne i Logue proponują tym samym waskie rozumienie dysjunktywizmu, zgodnie z którym percepcja i subiektywnie od niej nieodróżnialna halucynacja nie mają ze sobą nic mentalnie wspólnego, ponieważ nie istnieje taki mentalny rodzaj doświadczeń, do którego by wspólnie należały. Równocześnie jednak zwracają oni uwagę, że dopuszczalne jest także szerokie rozumienie, zgodnie z którym istnieje taki rodzaj, ale nie jest on fundamentalny (Byrne, Logue, 2009, s. XI). W świetle owego szerokiego rozumienia istnieje sens, w którym percepcja i subiektywnie od niej nieodróżnialna halucynacja są doświadczeniami tego samego rodzaju (ponieważ mają jakieś własności wspólne), ale nie są to doświadczenia tego samego fundamentalnego rodzaju (ponieważ różnią się ze względu na pewne inne własności, którym przyznaje się miano fundamentalnych).

W moim przekonaniu przytoczone wyżej wąskie rozumienie dysjunktywizmu jest chybioną charakterystyką tego twierdzenia. Jeśli percepcja i halucynacja mogą być subiektywnie nieodróżnialne, co przyzna każdy zwolennik dysjunktywizmu, to nie może być prawdą, że w takim przypadku nie mają one ze sobą nic mentalnie wspólnego (por. Crane, 2006, s. 139; Snowdon, 2009b, s. 58). Dlatego za trafną eksplikację dysjunktywizmu uznaję szerokie rozumienie ${ }^{3}$.

Byrne i Logue przyjmują wąskie rozumienie dysjunktywizmu, równocześnie zarysowując następującą panoramę stanowisk: dysjunktywizm (subiektywnie nieodróżnialne percepcje i halucynacje nie mają nic mentalnie wspólnego), pogląd ,umiarkowany” (subiektywnie nieodróżnialne percepcje i halucynacje różnią się pod pewnymi względami, zachowując pewien wspólny element) oraz pogląd „kartezjański” (jeśli dwa doświadczenia są subiektywnie nieodróżnialne dla podmiotu, to są „mentalnie identyczne”)

3 Przykładową konsekwencją przyjęcia szerokiego rozumienia dysjunktywizmu jest włączenie do grona zwolenników tego twierdzenia Marka Johnstona, który swoją teorię przedstawia w opozycji do wąskiego rozumienia dysjunktywizmu (zob. Johnston, 2009, s. 213-214). 
(Byrne, Logue, 2008, s. 70-71). Problem w tym, że gdyby taka charakterystyka była trafna, dysjunktywizm prawdopodobnie nie miałby żadnych zwolenników. Istnienie takich zwolenników jest między innymi pokłosiem faktu, że z ich punktu widzenia owa panorama może przedstawiać się nieco inaczej. Jedną z motywacji do przyjęcia dysjunktywizmu jest przekonanie, że różne formy intencjonalizmu, wskazywane przez Byrne'a i Logue jako „umiarkowane”, w ten czy inny sposób popadają w problemy nakreślonego przez nich poglądu „kartezjańskiego” (por. Martin, 2002, s. 413-419; Travis, 2013, s. 60, 85).

Byrne i Logue wprowadzili podział na pozytywne i negatywne wersje dysjunktywizmu (Byrne, Logue, 2008, s. 69). Te pierwsze dopuszczają podanie pozytywnej charakterystyki dla halucynacji subiektywnie nieodróżnialnych od percepcji. Z kolei te drugie przyjmują, że jedyna możliwa charakterystyka takich halucynacji sprowadza się do przypisania im negatywnej epistemicznej cechy bycia nieodróżnialnymi od percepcji na podstawie samej tylko introspekcji. Za waskim rozumieniem dysjunktywizmu Byrne i Logue argumentują, wskazując, że John Hinton - filozof często uznawany za pomysłodawcę tego twierdzenia - był zwolennikiem wersji negatywnej (Byrne, Logue, 2008, s. 69-70, [przypis 23], 81 [tekst główny oraz przypis 40]). Jest to nieprzekonujący i egzegetycznie wątpliwy argument $\mathrm{z}$ autorytetu ${ }^{4}$, który w dodatku nie wytrzymuje konfrontacji z licznymi racjami za przyznaniem ojcostwa dysjunktywizmu myślicielom znacznie wcześniejszym ${ }^{5}$. Mało tego, nawet negatywna wersja zakłada istnienie wspólnego czynnika pomiędzy omawianymi parami doświadczeń - jest nim wspomniana negatywna epistemiczna własność.

Dysjunktywizm w szerokim sensie może być zdefiniowany jako negacja tzw. Zasady Wspólnego Czynnika (Soteriou, 2010b). Najogólniej rzecz ujmując, zasada ta stwierdza, że percepcje i subiektywnie od nich nieodróżnialne halucynacje są doświadczeniami tego samego fundamentalnego rodzaju. Oczywiście szczegółowe sformułowania tej zasady różnią się w zależności od tego, jakie własności mają decydować o przynależności

4 „That there is, as I think, no such thing as my psi-ing, does not of itself prevent us from [...] asserting that there is something that happens both when I see a photic flash and when I have an illusion of one; only neither that happening nor any other happening would be my psi-ing. It would be absurd not to posit that happening, but this is no reason to identify it with, or marry it to, a chimaera" (Hinton, 2009b, s. 5).

5 Piszę o tym w innym tekście (zob. Zięba, b.d.w.). 
do rzeczonego fundamentalnego rodzaju. Różne wersje dysjunktywizmu wskazują tu na różne własności. W efekcie zwolennik jednej wersji dysjunktywizmu może akceptować Zasadę Wspólnego Czynnika sformułowaną przez zwolennika innej wersji dysjunktywizmu i vice vers $a^{6}$. Pozostając na pewnym poziomie ogólności, można wyróżnić metafizyczne i epistemologiczne sformułowania Zasady Wspólnego Czynnika. Pozwala to odróżnić od siebie metafizyczne i epistemologiczne wersje dysjunktywizmu.

Metafizyczne sformułowanie Zasady Wspólnego Czynnika dotyczy natury doświadczenia. Głosi ona, że subiektywnie nieodróżnialne percepcje, halucynacje i iluzje to jakościowo identyczne stany mentalne (por. Fish, 2010, s. 4). Z zasady tej wynika, że wewnętrzna natura doświadczenia może być identyczna w przypadku percepcji, halucynacji i iluzji. Subiektywnie nieodróżnialne percepcja, iluzja i halucynacja to trzy takie same stany mentalne, różniące się od siebie wyłącznie etiologią. Te stany mentalne mają się do siebie nawzajem niczym perfekcyjne kopie.

Tak rozumiana Zasada Wspólnego Czynnika leży u podstaw teorii, które Tim Crane zaklasyfikował razem pod ogólną nazwą „,intencjonalizm”. Według Crane’a fundamentalny problem we współczesnej analitycznej filozofii percepcji sprowadza się do pytania o to, czy percepcja jest relacją. W jego opinii wszystkie liczące się obecnie teorie percepcji można podzielić ze względu na to, czy odpowiadają na to pytanie przecząco, czy też twierdząco. Te pierwsze Crane grupuje pod szyldem ,intencjonalizm” (ang. intentionalism), z kolei tym drugim przypisuje zobowiązanie do twierdzenia znanego w anglojęzycznej literaturze pod nazwą disjunctivism (Crane, 2006, s. 128).

Użycie terminu ,intencjonalizm” w tak szeroki sposób można zakwestionować, stwierdzając, że do metafizycznej Zasady Wspólnego Czynnika zobowiązane są także inne teorie percepcji, które nie muszą lub nie moga przyjmować założenia, że doświadczenie posiada treść intencjonalną: teoria danych zmysłowych, teoria przysłówkowa, teorie przekonaniowe, teoria przyczynowa (por. Fish, 2010, passim). Mało tego, w literaturze broni się też intencjonalizmów zobowiązanych do dysjunktywizmu (zob. niżej). Dlatego

6 Typowym przykładem takiej sytuacji jest niechęć niektórych zwolenników epistemologicznej wersji dysjunktywizmu do zaprzeczania metafizycznej wersji Zasady Wspólnego Czynnika (ergo przyjmowania także metafizycznej wersji dysjunktywizmu). Piszę na ten temat szerzej w rozdziale 6. 
znacznie trafniejsze wydaje się tu określenie użyte przez Matthew Conducta - koniunktywizm (ang. conjunctivism). Conduct pisze, że dysjunktywizm w filozofii percepcji to negacja tezy, że percepcję można zdekomponować do (1) wystąpienia doświadczenia zmysłowego pojętego jako wewnętrzny stan podmiotu oraz (2) spełnienia pewnych dodatkowych warunków (np. wystąpienia określonej relacji przyczynowej pomiędzy przedmiotem istniejącym niezależnie od podmiotu a rzeczonym stanem podmiotu). Krótko mówiąc, na gruncie teorii koniunktywistycznych percepcja jest rozumiana jako koniunkcja (1) i (2) (Conduct, 2010, s. 202; por. Johnston, 2009, s. 208-209).

Metafizyczne sformułowanie dysjunktywizmu (ang. metaphysical disjunctivism) zaprzecza, jakoby subiektywnie nieodróżnialne percepcje, halucynacje i iluzje były egzemplifikacjami tego samego typu stanu mentalnego. Dlaczego? Wyjaśnienie motywacji stojących za negacją scharakteryzowanego koniunktywizmu wymaga pewnych uściśleń pojęciowych.

\section{Natura percepcyjnej relacji}

Jak zwraca uwagę Fiona MacPherson, chociaż czasownik ,postrzegać” (ang. to perceive) oznacza skuteczne nawiązanie kontaktu ze światem istniejącym niezależnie od postrzegającego podmiotu i w związku z tym kontrastuje z „doświadczaniem halucynacji” (ang. to hallucinate), to jednak w literaturze częste jest używanie wyrażenia „doświadczenie percepcyjne” (ang. perceptual experience) w sensie ogólniejszym, tzn. obejmującym swoim zasięgiem zarówno percepcje, jak i halucynacje (MacPherson, 2014, s. 1). Odrzucam tę praktykę jako potencjalne źródło ekwiwokacji i nieporozumień.

Chcąc zachować neutralność wobec obydwu stron opisywanej tu debaty, będę się posługiwać określeniem „doświadczenie zmysłowe”, które definiuję bardzo ogólnie: jest to zjawisko dane świadomości w formie jednej bądź kilku modalności zmysłowych. Bardziej precyzyjna definicja wymagałaby już przyjęcia jednej z konkurujących perspektyw. Tylko niektóre spośród tak pojętych doświadczeń zmysłowych są percepcyjne: te, które 
włączają podmiot $\mathrm{w}$ relację z przedmiotem niezależnie od tego podmiotu istniejącym ${ }^{7}$.

Ktoś mógłby w tym momencie zapytać, czy tak rozumiane doświadczenie zmysłowe jest tym fundamentalnym rodzajem doświadczeń, którego istnienie neguje dysjunktywizm. Odpowiedź brzmi: nie, ponieważ podana definicja doświadczenia zmysłowego jest neutralna wobec Zasady Wspólnego Czynnika. $Z$ dysjunktywizmu nie wynika, że nakreślone przeze mnie ogólne pojęcie doświadczenia zmysłowego jest pustą kategorią ${ }^{8}$. Przedmiotem sprzeciwu zwolenników dysjunktywizmu jest coś innego, a mianowicie uznawanie każdego doświadczenia zmysłowego za wewnętrzny stan doświadczającego podmiotu. Widać to wyraźnie już w tekstach Hintona:

[...] byłoby absurdem nie postulować podobnych zdarzeń we mnie, kiedy widzę błysk światła i kiedy doznaję iluzji takiego błysku. Dlatego łatwo pomylić te postulowane zdarzenia z subiektywnymi zdarzeniami, do których wprowadzenia skłania nas nasz „zły duch” [...] Nie przeczę, że widzenie pociąga za sobą doświadczenie wzrokowe. Widzenie czegoś jest doświadczeniem [...] (Hinton, 2009b, s. 10).

[...] specjalne, filozoficzne pojęcie doświadczenia, [...] w pierwszych akapitach tej książki było przeze mnie traktowane jako zawierające pew-

7 Mam tu na myśli paradygmatyczne rozumienie pojęcia „,doświadczenie zmysłowe”. Domniemane przypadki percepcji nieświadomej (np. ślepowidzenie, zespół nieuwagi stronnej, percepcja podprogowa) nie stanowią problemu dla tej definicji. Nawiasem mówiąc, istnieją poważne argumenty podające w wątpliwość możliwość wystąpienia nieświadomej percepcji (zob. Phillips, b.d.w.).

8 Aczkolwiek zdaniem niektórych zwolenników dysjunktywizmu halucynacje w ogóle nie są doświadczeniami. Tak uważa Thau, według którego najogólniejszym rodzajem obejmującym zarówno percepcje, iluzje, jak i halucynacje, są appearances. Ów techniczny termin jest rzeczownikiem utworzonym od czasownika to appear, który oznacza „wydawać się”, „wyglądać”, ,jawić się”. W literaturze terminu appearance używa się niekiedy w odniesieniu do danych zmysłowych, jednakże tutaj chodzi o taki jego sens, jakim posługuje się J. McDowell. Dla McDowella appearance to nie przedmiot doświadczenia, lecz sytuacja, w której podmiotowi wydaje się, że rzeczy mają się w taki a taki sposób; w której podmiot ma wrażenie percepcyjnego uświadomienia sobie zachodzenia jakiegoś faktu. Tak pojęte appearance trafnie oddaje zarówno to, co dzieje się podczas halucynacji, jak i to, co zachodzi w ramach percepcji. Tak rozumiane appearance jest również, przynajmniej w przybliżeniu, równoznaczne z przyjętą przeze mnie powyżej definicją doświadczenia zmysłowego (por. Byrne, Logue, 2008, s. 65-66; McDowell, 1998, s. 386-387; Thau, 2004, s. 195, 250-251). 
ną ogólną ideę: doświadczenie wzrokowe jest ,wewnętrzne” niezależnie od stopnia, w jakim zawdzięcza ono swe znaczenie doświadczeniu życia swojego podmiotu. [...] Tak pojęte doświadczenie miałoby występować zarówno wtedy, gdy percypujesz błysk światła, jak i wtedy, gdy masz iluzję, że widzisz taki błysk (Hinton, 2009a, s. 23).

Dysjunktywizm jest zatem wymierzony nie w samą kategorię doświadczenia zmysłowego, ale w jej specyficzne, filozoficznie ,naładowane” rozumienie, które zakłada Zasadę Wspólnego Czynnika (por. Snowdon, 2008, s. 44).

Mając na uwadze te ustalenia, możemy podać następującą koniunktywistyczną definicję percepcji: jest to doświadczenie zmysłowe rozumiane jako wewnętrzny stan podmiotu i włączające podmiot w przyczynową relację z postrzeganym przedmiotem. Prima facie definicja ta stoi w jawnej sprzeczności z przytoczoną wcześniej tezą Crane'a, jakoby koniunktywizm (vel ,intencjonalizm”) negował istnienie percepcyjnej relacji. Wszak to teorie zakładające dysjunktywizm miały twierdząco odpowiadać na pytanie o relacyjny charakter percepcji, negując tezę koniunktywistyczną. Ta pozorna sprzeczność jest efektem pewnej dwuznaczności związanej z użyciem pojęcia „relacji” w rozpatrywanym kontekście. Oddajmy głos Crane’owi:

Percepcja jest reprezentacją świata [...] nie zawsze jest prawdą, że jeśli $\mathrm{X}$ reprezentuje $\mathrm{Y}$, to $\mathrm{Y}$ musi istnieć. Zatem istota percepcyjnej reprezentacji nie obejmuje relacji do tego, co jest reprezentowane. To jest intencjonalistyczna koncepcja percepcji [...]. Percepcja jest autentyczną relacją ze światem, ale halucynacja to zaledwie zjawisko albo zaledwie reprezentacja; i nie istnieje bardziej fundamentalny rodzaj stanu mentalnego (,doświadczenie percepcyjne”), do którego razem należą. To jest dysjunktywistyczna koncepcja percepcji [...] (Crane, 2006, s. 133).

Przedstawione tu przez Crane'a dwie konkurencyjne teorie stanowią dwie możliwe odpowiedzi na argument $\mathrm{z}$ halucynacji oraz bliźniaczy argument z iluzji. Obydwa argumenty wychodzą od przesłanki, że dla dowolnego doświadczenia percepcyjnego możliwa jest subiektywnie od niego nieodróżnialna halucynacja (lub iluzja). Skoro dokładnie takie samo doświadczenie może wystąpić z udziałem i bez udziału przedmiotu istniejącego niezależnie od podmiotu, to znaczy, że relacja z takim przedmiotem nie jest esencjalną cechą doświadczenia (niezależnie od tego, czy owo doświadczenie jest percepcją, iluzją czy halucynacją) (Crane, 2011). Koniunktywista przyjmuje wnioski tych argumentów wraz ze wszystkimi konsekwencjami, natomiast 
zwolennik metafizycznej wersji dysjunktywizmu odrzuca je. Dla koniunktywisty percepcyjna relacja ma charakter przyczynowy i przygodny, z kolei jego oponent przypisuje jej charakter konstytutywny i konieczny. W świetle metafizycznego sformułowania dysjunktywizmu dane doświadczenie jest percepcją tylko wtedy, gdy jest współkonstytuowane przez postrzegany przedmiot istniejący niezależnie od podmiotu. Owo współkonstytuowanie oznacza, że podmiot i przedmiot pozostają ze sobą nawzajem w relacji bycia częściami pewnej całości, jaką jest doświadczenie percepcyjne. Halucynacja, nawet jeśli z punktu widzenia podmiotu jest subiektywnie nieodróżnialna od percepcji, nie ma przedmiotu wśród swoich części składowych (Fish, 2010, s. 91).

Kiedy Crane pisze, że koniunktywista zaprzecza relacyjnemu charakterowi percepcji, przypisuje koniunktywiście negację tezy, że istnienie relacji z przedmiotem istniejącym niezależnie od podmiotu jest koniecznym warunkiem zaistnienia doświadczenia percepcyjnego (ponieważ zdaniem koniunktywisty takie samo doświadczenie może wystąpić w przypadku halucynacji). Wszelkie wątpliwości ${ }^{9}$ dotyczące tego, co Crane rozumie przez percepcyjną relację (przyczynowa czy konstytutywna?), rozwiewa poczynione przez niego odwołanie (Crane, 2006, s. 133) do Johna Campbella, który relacyjny pogląd na percepcję charakteryzuje w następujący sposób:

9 Na przykład Adriana Schetz (Schetz, 2014, s. 260, 281) przedstawia omawiany tu spór w sposób odwrotny do tego, w jaki robi to Crane, pisząc, że (1) realizm naiwny jest zobowiązany do odrzucenia tezy o relacyjności percepcji oraz (2) intencjonalizm i reprezentacjonalizm to relacyjne teorie percepcji. Mogłoby się wydawać, że Schetz ma tu na myśli relację przyczynową pomiędzy doświadczeniem a postrzeganym przedmiotem, jednakże w tej samej pracy używa nazwy „,relacyjna koncepcja doświadczenia” w odniesieniu do realizmu naiwnego Johna Campbella. Relacyjna koncepcja percepcji broniona przez zwolenników standardowej wersji dysjunktywizmu metafizycznego opiera się na relacji konstytuowania, a nie na relacji przyczynowej (por. Fish, 2010, s. 96: ,Typically, the motivation for endorsing disjunctivism about phenomenology is to defend a philosophical theory of the good cases of perception known as naive realism or relationalism" [Martin, 2009b, s. 94]:,,[...] the intentional approach agrees with the naive realist about what is "before the mind," namely the external objects of perception, but it disagrees with it about the manner in which the objects of perception are before the mind. The naive realist thinks of this relationally: the objects are part of the relational state of affairs which comprises perceptual experience. The intentional theorist denies this relational character. Experience is rather quasi-relational: it has a character such that it is as if the objects of perception are before the mind, but they are not required to be so in order for one to be in this state"). 
Na gruncie Poglądu Relacyjnego, jakościowy charakter doświadczenia jest konstytuowany przez jakościowy charakter postrzeganej sceny. [...] tylko taki pogląd, zgodnie $\mathrm{z}$ którym doświadczenie przedmiotu jest prostą relacją pomiędzy postrzegającym a przedmiotem, jest w stanie scharakteryzować rodzaj zaznajomienia z przedmiotami, który dostarcza wiedzy o odniesieniu (Campbell, 2002, s. 114-115).

\section{Metafizyczne wersje dysjunktywizmu}

Na czym dokładnie ma polegać owo konstytuowanie percepcji przez postrzegany przedmiot? Tutaj zwolennicy metafizycznej wersji dysjunktywizmu odpowiadają na różne sposoby. Każdy z nich opiera się na uznaniu któregoś z wymienionych przeze mnie rodzajów własności za kluczowe dla odróżnienia percepcji od subiektywnie od niej nieodróżnialnej halucynacji.

Michael G.F. Martin uważa, że wspomniana metafizyczna różnica pomiędzy percepcją a subiektywnie od niej nieodróżnialną halucynacją dotyczy własności fenomenalnych tych doświadczeń. Jego zdaniem doświadczenie zmysłowe charakteryzuje się przezroczystością (ang. transparency), co oznacza, że w doświadczeniu introspektywnie dostępne są wyłącznie własności doświadczanego przedmiotu (Martin, 2009a, s. 273). Na przykład w doświadczeniu niebieskiej powierzchni nie ma nic poza niebieską powierzchnią. Kluczowe jest tu jednak inne twierdzenie: wspomniane własności przedmiotu konstytuują charakter fenomenalny doświadczenia ${ }^{10}$. W związku z tym zaistnienie doświadczenia percepcyjnego bez relacji z postrzeganym przedmiotem nie jest możliwe (Martin, 2009a, s. 273).

Jak w takim razie wytłumaczyć możliwość wystąpienia halucynacji subiektywnie nieodróżnialnej od percepcji? Martin ma tu do zaoferowania czysto negatywną koncepcję, zgodnie z którą o owej nieodróżnialnej halucynacji nie można powiedzieć nic poza tym, że jest ona nieodróżnialna od

10 To twierdzenie odróżnia koncepcję Martina od intencjonalistycznej teorii przyjmującej tezę o przezroczystości doświadczenia, czyli reprezentacjonalizmu. Według reprezentacjonalistów własności przedmiotu nie konstytuują charakteru fenomenalnego doświadczenia, lecz są w nim reprezentowane (por. Fish, 2010, s. 79). Martin uważa, że to właśnie ta różnica w rozumieniu przezroczystości doświadczenia czyni spór pomiędzy zwolennikami dysjunktywizmu a intencjonalistami naprawdę istotnym (zob. Martin, 2002, s. 395). 
percepcji na podstawie samej tylko introspekcji. Według Martina ta skromna odpowiedź musi nam wystarczyć, ponieważ (1) nasze ogólne pojęcie doświadczenia wzrokowego jest jedynie derywatem pojęcia doświadczenia percepcyjnego (Martin, 2006, s. 363-364) oraz (2) nie jesteśmy nieomylni w kwestii fenomenalnego charakteru naszych doświadczeń (Martin, 2009a, s. $280-281)^{11}$.

Obydwie tezy wymagają rozwinięcia. Pierwsza z nich to negacja pozornie intuicyjnego poglądu, że ogólne pojęcie ,doświadczenie zmysłowe" wyznacza pewną podstawową kategorię zjawisk, do której percepcje, halucynacje i iluzje przynależą jako subkategorie. W tym sensie ogólniejsza kategoria doświadczenia wzrokowego może być uznana za pierwotną w stosunku do bardziej konkretnej kategorii percepcji wzrokowej (rozumianej jako skuteczne nawiązanie poznawczego kontaktu ze światem). Pogląd ten zakłada jednak, że najbardziej fundamentalnym kryterium podziału doświadczeń jest ich charakter fenomenalny. Martin odrzuca to założenie. Owym fundamentalnym kryterium jest dla niego włączanie podmiotu w poznawczy kontakt ze światem. Z tej perspektywy halucynacje i iluzje to zaledwie nieudane próby postrzeżenia czegoś. Uznajemy je za doświadczenia zmysłowe właśnie dlatego, że są podobne do percepcji. Dlatego percepcja wzrokowa jest czymś bardziej fundamentalnym niż doświadczenie wzrokowe. Kategoria percepcji zmysłowej jest prototypem dla kategorii doświadczenia zmysłowego i w tym sensie jest od niej bardziej fundamentalna.

Druga teza wyraża sprzeciw wobec pewnego postkartezjańskiego reliktu, zgodnie z którym podmiot ma specjalny epistemiczny dostęp do swojej perspektywy pierwszoosobowej: mogę się mylić w kwestii tego, do czego moje doświadczenia się odnoszą, ale nie mogę się mylić odnośnie do ich treści ani do tego, że je mam. Nie jesteśmy nieomylni w tym sensie, ponieważ treść naszych doświadczeń jest transparentna i konstytuowana przez własności doświadczanych przedmiotów.

Stanowisko Martina staje się bardziej przekonujące, kiedy uwzględni się stojące za nim motywacje. Najważniejszą z nich jest chęć uniknięcia tzw. sceptycyzmu Hume'owskiego, do którego nieuchronnie prowadzi koniunktywizm. Jeżeli dokładnie to samo doświadczenie może wystąpić

11 Obrona tego dość kontrowersyjnego stanowiska nie należy do celów niniejszego artykułu, niemniej warto zwrócić uwagę na bardzo interesujące rozwinięcie myśli Martina zaproponowane przez Matthew Soteriou (Soteriou, 2005). 
w przypadku percepcji i halucynacji, to niepodobna wytłumaczyć, na czym polega zdolność zmysłów do włączania podmiotu w relację ze światem istniejącym niezależnie od umysłu. Uniemożliwia to tzw. problem przesłonięcia (ang. screening-off problem).

Termin ,przesłonięcie” odnosi się do pewnej specyficznej zależności pomiędzy trzema elementami (X, Y i Z): jeżeli w sytuacji S jest obecny X, to ewentualna obecność Y w S nie ma wpływu na prawdopodobieństwo, że w S wystąpi także Z. Innymi słowy, obecność X w S sprawia, że obecność Z w S jest ,probabilistycznie niezależna” od obecności Y w S (Hellie, 2014, s. 153).

W rozpatrywanym kontekście $\mathrm{X}$ to kwestionowany przez dysjunktywistów wspólny czynnik pomiędzy percepcją a halucynacją (np. reprezentacja percepcyjna albo dana zmysłowa), Y to relacja ze światem istniejącym niezależnie od podmiotu, natomiast $\mathrm{Z}$ to przekonanie podmiotu o tym, że widzi jakiś przedmiot.

Problem przesłonięcia pojawia się jako konsekwencja identyfikowania doświadczenia z jego charakterem fenomenalnym. Przyjmijmy, że percepcja $\mathrm{P}$ i halucynacja $\mathrm{H}$ mają jakościowo identyczne charaktery fenomenalne, FP i FH. Skoro są one identyczne, to superweniują na takiej samej aktywności mózgu B. Jakakolwiek byłaby zatem różnica pomiędzy doświadczeniami P i H (relacja ze światem istniejącym niezależnie od podmiotu, wartość epistemiczna itd.), zostanie ona przesłonięta przez wspomniane charaktery fenomenalne i tkwiącą u ich podstaw aktywność mózgu B (Fish, 2010, s. 99).

Martin argumentuje w następujący sposób: jeżeli percepcyjna relacja $\mathrm{z}$ istniejącym niezależnie od podmiotu przedmiotem $\mathrm{O}$ jest przesłonięta przez charakter fenomenalny doświadczenia, to nie odgrywa ona żadnej przyczynowej ani eksplanacyjnej roli, która byłaby istotna dla wyjaśnienia sądu percepcyjnego ,widzę O” (Martin, 2009a, s. 292-293). Aby usunąc problem przesłonięcia i zagwarantować percepcyjnej relacji ową przyczynową i eksplanacyjną rolę, musimy przyjąć, że charakter fenomenalny percepcji jest konstytuowany przez $\mathrm{O}$.

Jak słusznie zauważył Benj Hellie, argumentacja Martina opiera się na dwóch dodatkowych założeniach: (1) przesłonięcie należy tu rozumieć jako relację asymetryczną; (2) nie ma żadnych racji unieważniających tezę, że przesłonięcie wyklucza zachodzenie relacji przyczynowej pomiędzy wystąpieniem relacji percepcyjnej z przedmiotem O a sądem „widzę O”. 
Argument zakłada bowiem, że warunkiem koniecznym, ,powodowania” jest „robienie różnicy” (tzn. różne przyczynowe historie percepcji i subiektywnie od niej nieodróżnialnej halucynacji nie mogą odgrywać owej przyczynowej i eksplanacyjnej roli, ponieważ nie robią żadnej różnicy w wewnętrznym stanie podmiotu). Jednakże, jak zwraca uwagę Hellie, nasza ograniczona wiedza dotycząca natury przyczynowości nie pozwala nam wykluczyć możliwości, że „powodowanie” nie wymaga „robienia różnicy” (Hellie, 2014, s. 153, przypis 2, s. 159-162).

Przedstawiona koncepcja Martina ma na celu nie tylko przezwyciężenie sceptycyzmu Hume'a, ale także zagwarantowanie możliwości formułowania myśli i sądów demonstratywnych (dotyczących konkretnych obiektów w świecie), czego domaga się cytowany już Campbell (Campbell, 2002, s. 114). Postulowaną przez Campbella partykularność doświadczenia percepcyjnego próbuje się uzyskać także poprzez formułowanie dysjunktywizmu w odniesieniu do własności intencjonalnych doświadczenia ${ }^{12}$. Michael Tye, jeden ze zwolenników tego stanowiska, twierdzi, że percepcja i subiektywnie od niej nieodróżnialna halucynacja mają różne treści propozycjonalne oraz identyczne charaktery fenomenalne. Treść propozycjonalna percepcji jest identyfikowana poprzez odniesienie do konkretnego przedmiotu. Z kolei treść propozycjonalna halucynacji nie zawiera odniesienia do przedmiotu (albo zawiera nieudane odniesienie - Tye przedstawia tu dwa możliwe rozwiązania), nawet jeśli jest to halucynacja subiektywnie nieodróżnialna od percepcji. Wreszcie dopuszczenie identyczności percepcji i halucynacji pod względem fenomenalnego charakteru ma tłumaczyć możliwość subiektywnej nieodróżnialności, o której była mowa (Tye, 2007, 2014).

Matthew Soteriou zwraca uwagę, że dysjunktywizm w kwestii treści intencjonalnej doświadczenia nie powinien być mylony z eksternalizmem w kwestii treści doświadczenia. Soteriou powołuje się tu na przykład Tylera

12 Campbell nie zaakceptowałby jednak takiego rozwiązania (,,Of course, the individuation of representational contents may be thought to depend on factors concerning the environment. But given a single background environment, you could have representational contents relating to daggers and their characteristics whether or not there actually was a dagger in front of you. So the phenomenal character of your experience could be exactly the same in both cases. [...] On the Relational View, in contrast, there is nothing intrinsic in common between the cases in which there is a dagger to which you are consciously attending, and the case in which you are just having a hallucination" [Campbell, 2002, s. 117]). 
Burge'a, filozofa skrajnie niechętnego teoriom zakładającym dysjunktywizm (zob. Burge, 2005, 2011), który akceptując różnicę pomiędzy percepcją a halucynacją, wciąż uważa je za doświadczenia tego samego rodzaju. Innego zdania jest Tye, który otwarcie przypisuje sobie zobowiązanie do pewnej wersji dysjunktywizmu (Tye, 2007, s. 609). Obydwaj myśliciele zgadzają się co do tego, że treść propozycjonalna doświadczenia jest inna w przypadku percepcji i subiektywnie od niej nieodróżnialnej halucynacji. Jednakże Burge, w odróżnieniu od Tye'a, nie wyciąga stąd wniosku, że percepcje i halucynacje są różnymi rodzajami doświadczeń. Stwierdzenie różnicy w treści propozycjonalnej pomiędzy percepcją a halucynacją nie implikuje jeszcze, że są to doświadczenia fundamentalnie różnego rodzaju (Soteriou, 2000, s. 186).

Podając przykłady dysjunktywizmów metafizycznych, nieprzypadkowo zestawiam koncepcje Martina i Tye'a. Zestawienie to pokazuje bowiem, jak szerokiemu spektrum teorii percepcji można przypisać zobowiązanie do rzeczonej tezy ${ }^{13}$. O ile teoria Martina jest często przedstawiana jako wzorcowy przykład dysjunktywizmu, o tyle zaklasyfikowanie w ten sposób propozycji Tye'a może budzić pewne wątpliwości. Istotną różnicę pomiędzy teoriami Martina i Tye'a wyznacza bowiem ich stosunek do natury percepcyjnej relacji. Według Martina ma ona charakter konstytuujący. Zdaniem Tye'a - przyczynowy (Tye, 2007, s. 594). Jeżeli uznamy, że Tye trafnie dostrzega w swojej koncepcji pewną wersję dysjunktywizmu, to będziemy musieli przyznać, że sprzeciw wobec przyczynowej teorii percepcji nie jest elementem wspólnym dla wszystkich dysjunktywizmów metafizycznych. Pogląd broniony przez Tye'a to przykład poglądu ,umiarkowanego" w zarysowanej przeze mnie terminologii Byrne'a i Logue (ang. the moderate view) (Byrne, Logue, 2009, s. X; argumenty na rzecz tego poglądu można też znaleźć w: Schellenberg, 2014; Schetz, 2007; Siegel, 2010, s. 74). Według Tye'a percepcja i subiektywnie od niej nieodróżnialna halucynacja mają pewne własności wspólne (w obydwu przypadkach częścią składową treści intencjonalnej doświadczenia jest taka sama wiązka własności określająca charakter fenomenalny), ale różnią się z uwagi na pewne inne własności (pomiędzy percepcją a halucynacją występuje różnica w treści propozycjonalnej) (Tye, 2014, s. 306-307).

13 Dokładny przegląd stanowisk znajdujących się w obrębie tego spektrum można znaleźć w książce Susanny Siegel (2010, s. 164-169). 
Nie ma nic dziwnego w tym, że stanowiska umiarkowane, łączące ze sobą pewne elementy zapożyczone od stanowisk bardziej skrajnych i sobie nawzajem przeciwstawnych, są trudne do zaklasyfikowania. Siegel radzi sobie $\mathrm{z}$ tą trudnością, określając teorie umiarkowane (do których zalicza także stanowisko Tye'a) jako disjunctive internalism oraz content disjunctivism i stawiając je poza zasięgiem pure disjunctivism (Siegel, 2010, s. 74, 167).

\section{Metafizyczne wersje dysjunktywizmu a natura percepcyjnej relacji}

Tye wychodzi od podobnych motywacji, co Campbell i Martin, ale nie osiąga ich celu. Uznanie przyczynowego charakteru percepcyjnej relacji czyni jego koncepcję podatną na problem przesłonięcia. Czy wobec tego poszukiwaną tu kwintesencją dysjunktywizmu jest sprzeciw wobec przyczynowej teorii percepcji? Do takiego wniosku może prowadzić lektura artykułów jednego z pierwszych filozofów otwarcie wykorzystujących dysjunktywizm w swojej argumentacji. Paul Snowdon - bo o nim mowa - nie stara się pokazać, że twierdzenie to jest prawdziwe. Jego argumentacja polega raczej na wskazaniu, że skoro dysjunktywizm może być prawdziwy (tzn. jego fałszywość nie jest oczywista), to przyczynowa teoria percepcji ${ }^{14}$ nie jest prawdą pojęciową (Byrne, Logue, 2008, s. 72; Snowdon, 2009a, s. 47), tzn. nie jest prawdziwa wyłącznie na mocy znaczeń terminów zawartych w jej sformułowaniu (por. Chalmers, 2010, s. 108).

Snowdon zwraca uwagę, że obydwa stanowiska podają różne wyjaśnienia dla tzw. werydycznej halucynacji, czyli doświadczenia prezentującego przedmiot zgodnie z rzeczywistością (a więc dokładnie tak, jak w przypadku percepcji), pomimo niezachodzenia jakiegokolwiek związku pomiędzy doświadczeniem a przedmiotem. Jeden z przytoczonych przez niego przykładów opowiada o człowieku, który kieruje swój wzrok na stojący przed nim zegar i równocześnie doznaje halucynacji identycznego zegara, będącej skutkiem stymulowania jego kory wzrokowej przez naukowców. Chociaż doświadczenie tego człowieka jest subiektywnie nieodróżnialne od percepcji

14 Snowdon pisze o ,przyczynowej teorii widzenia”, jednakże dla uproszczenia wywodu zastąpiłem ten termin bardziej ogólnym określeniem ,przyczynowa teoria percepcji” (por. Snowdon, 2009a, s. 35). 
zegara, której z pewnością doświadczyłby, nie podlegając wspomnianej stymulacji, to nie możemy uznać, że człowiek ten widzi stojący przed nim zegar (Snowdon, 2009a, s. 38) ${ }^{15}$.

$\mathrm{Na}$ gruncie teorii przyczynowej werydyczna halucynacja nie jest percepcją, ponieważ nie zachodzi odpowiednia przyczynowa relacja pomiędzy przedmiotem a doświadczeniem; jednakże wewnętrzna natura percepcji i subiektywnie od niej nieodróżnialnej werydycznej halucynacji jest jakościowo identyczna, gdyż przedmiot subiektywnie (fenomenalnie) jawi się podmiotowi tak samo w obydwu przypadkach (zgodnie z Zasadą Wspólnego Czynnika). Temu właśnie zaprzecza dysjunktywizm, zgodnie z którym percepcja i werydyczna halucynacja są doświadczeniami dwóch różnych rodzajów. Kontrast pomiędzy dysjunktywizmem a przyczynową teorią percepcji bierze się stąd, że ta ostatnia traktuje doświadczenie jako wewnętrzny (ang. inner) stan podmiotu, który może być wywołany na różne sposoby i w konsekwencji wystąpić zarówno w przypadku percepcji, jak i w przypadku werydycznej halucynacji (Snowdon, 2009b, s. 51, 54). Dysjunktywizm zaprzecza istnieniu takiego wewnętrznego stanu, który byłby wspólnym czynnikiem dla subiektywnie nieodróżnialnych percepcji i halucynacji. Skoro możliwe jest więcej niż jedno wyjaśnienie werydycznej halucynacji, teoria przyczynowa nie może być prawdą pojęciową. Snowdon twierdzi, że zwolennicy tej teorii przyjmują ją na drodze wnioskowania do najlepszego wyjaśnienia (abdukcji) (Snowdon, 2009a, s. 39), chociaż nie jest wcale oczywiste, że jest ona tutaj najlepszym wyjaśnieniem.

Komentując rozważania Snowdona, Byrne i Logue zwracają uwagę, że teoria przyczynowa może być traktowana jako przeciwieństwo dysjunktywizmu tylko o tyle, o ile jest zobowiązana do metafizycznej Zasady Wspólnego Czynnika (Byrne, Logue, 2009, s. XXV, przypis 23). Na gruncie przyjmujących tę zasadę stanowisk koniunktywistycznych przyczynowa relacja łącząca podmiot $\mathrm{z}$ przedmiotem jest przygodna $\mathrm{w}$ tym sensie, że takie samo doświadczenie może wystąpić bez jej udziału. Jej obecność nie jest konieczna do wystąpienia takiego doświadczenia. Tymczasem w przypadku umiarkowanego stanowiska bronionego przez Tye'a relacja ta jest konieczna, ponieważ doświadczenie o takiej samej treści nie może wystąpić bez jej udziału.

15 Snowdon posługuje się tu terminem „U-cases” (ang. unseen cases), jest jednak jasne, że ma na myśli halucynacje werydyczne (por. MacPherson, 2014, s. 6). 
Snowdon dopuszcza możliwość takiego sformułowania przyczynowej teorii percepcji, które nie zakładałoby opisanego internalistycznego poglądu na wewnętrzną naturę doświadczenia. Jednakże równocześnie stwierdza, że byłoby to sformułowanie odbiegające od tradycyjnego (które wywodzi od H.P. Grice'a) i pozbawione przekonującego uzasadnienia (Snowdon, 2009b, s. 52).

Warto tu przypomnieć wspomnianą już różnicę pomiędzy koncepcjami Burge'a i Tye’a. Obydwaj myśliciele uważają, że percepcyjna relacja ma charakter przyczynowy. Obydwaj twierdzą, że treść propozycjonalna doświadczenia jest jednostkowa (ang. singular), czyli odnosi się do konkretnego przedmiotu w świecie. Nie jest ogólnym opisem, który różne przedmioty mogą spełniać w zależności od kontekstu. Wreszcie obydwaj utrzymują, że treść propozycjonalna jest zależna od reprezentowanego przez doświadczenie obiektu (ang. object dependent), a więc nie może być taka sama w przypadku percepcji i halucynacji. Jednakże w przeciwieństwie do Tye'a, Burge zaprzecza, jakoby uznawanie wymienionych tu różnic zobowiązywało go do uznania, że percepcje i halucynacje mają odmienne wewnętrzne natury (Burge, 1991, s. 198-199, 208-209). Zatem nie stosunek do natury percepcyjnej relacji, lecz pogląd na naturę treści doświadczenia pozwala wyróżnić zwolenników i przeciwników dysjunktywizmu metafizycznego wśród intencjonalistów.

Wobec tego zasadne będzie uznanie umiarkowanych koncepcji pokroju tej bronionej przez Tye'a za umiarkowane wersje dysjunktywizmu metafizycznego. Teorie te postulują bowiem zachodzenie metafizycznej różnicy pomiędzy wewnętrznymi naturami percepcji i subiektywnie od niej nieodróżnialnej halucynacji (por. Soteriou, 2005, s. 189).

W tym miejscu warto przywołać cytowaną już tezę Crane'a, zgodnie z którą dysjunktywizm metafizyczny jest zobowiązany do twierdzenia, że percepcja jest relacją. Uznanie koncepcji Tye’a za przykład metafizycznej wersji dysjunktywizmu nie będzie precedensem podważającym tę regułę. Jeżeli Tye uważa, że percepcja koniecznie wymaga relacji podmiotu z niezależnie od niego istniejącym przedmiotem, to można tu mówić o współkonstytuowaniu percepcji przez przedmiot w jakimś słabym sensie, nawet jeśli rzeczona relacja jest zaledwie przyczynowa.

Osobną kwestią jest wiarygodność tej koncepcji. Tye utrzymuje, że elementem wspólnym pomiędzy percepcją i subiektywnie od niej nieodróżnialną halucynacją jest wiązka własności określająca charakter fenomenalny. 
W treści intencjonalnej percepcji reprezentowane są własności obiektów w świecie, z kolei w treści intencjonalnej halucynacji reprezentowane są własności nieskonkretyzowane (ang. un-instantiated), czyli... powszechniki (Tye, 2007, s. 305-306 oraz przypis 20$)^{16}$. Skoro taki sam charakter fenomenalny może wystąpić zarówno w treści intencjonalnej percepcji, jak i w treści intencjonalnej halucynacji, to powstaje zagrożenie, że przesłoni on różnicę pomiędzy treściami propozycjonalnymi tych doświadczeń. Nie jest zatem jasne, jak dysjunktywizm w kwestii treści intencjonalnej doświadczenia radzi sobie z problemem przesłonięcia. Skądinąd trudno się dziwić, że stanie okrakiem nad gardzielą największej przepaści we współczesnej filozofii percepcji nie jest pozycją komfortową.

\section{Epistemologiczne wersje dysjunktywizmu}

Podobne wątpliwości może budzić epistemologiczne sformułowanie dysjunktywizmu. Jest ono negacją epistemologicznej wersji Zasady Wspólnego Czynnika, zgodnie z którą uzasadnienie epistemiczne przekonania opartego na percepcji nie jest lepsze niż uzasadnienie epistemiczne przekonania opartego na halucynacji subiektywnie nieodróżnialnej od tej percepcji (McDowell, 1998, s. 386; zob. też 2013b, s. 262). Ujmując to inaczej, elementem wspólnym pomiędzy subiektywnie nieodróżnialnymi przypadkami percepcji, halucynacji i iluzji jest ich epistemiczna ważkość, ponieważ przekonaniom percepcyjnym formułowanym na podstawie tych doświadczeń przysługuje takie samo uzasadnienie epistemiczne.

Akceptacja tej wersji Zasady Wspólnego Czynnika leży u podstaw dwóch tradycyjnych teorii uzasadnienia: internalizmu i eksternalizmu. Internalizm epistemiczny głosi, że uzasadnienie jest zależne wyłączenie od czynników wewnętrznych względem podmiotu. Eksternalizm epistemiczny to teza, że uzasadnienie jest determinowane także przez czynniki zewnętrzne względem podmiotu. Internalizm najczęściej przybiera jedną z dwóch postaci: akcesybilizmu (uzasadnienie jest dostępne dla podmiotu na drodze racjonalnej refleksji) lub mentalizmu (uzasadnienie superweniuje na stanach mentalnych podmiotu). Z kolei eksternalizm wiąże się z reliabilizmem,

16 Tye nie jest tutaj odosobniony. Zwolennikiem poglądu, że przedmiotami halucynacji są powszechniki, był również Fred Dretske (zob. Dretske, 2000, s. 163). 
według którego przekonanie jest uzasadnione wtedy, gdy zostało sformułowane zgodnie ze sprawdzoną procedurą (tzn. taką, która w większości przypadków prowadzi do prawdziwych przekonań) (Madison, 2010; zob. też Pryor, 2001, s. 103-109) ${ }^{17}$.

Dysjunktywizm epistemologiczny to teoria uzasadnienia, która W założeniu ma godzić ze sobą prima facie sprzeczne intuicje stojące za internalizmem i eksternalizmem. Stwierdza ona, że doświadczenie percepcyjne, w przeciwieństwie do subiektywnie od niego nieodróżnialnych iluzji i halucynacji, jest źródłem uzasadnienia epistemicznego, które jest równocześnie dostępne dla podmiotu na drodze samej tylko refleksji (wymóg internalizmu-akcesybilizmu) i ugruntowane w faktach niezależnych od podmiotu (wymóg eksternalizmu). Zwolennikami tak rozumianego dysjunktywizmu epistemologicznego są John McDowell (McDowell, 2010, s. 247) i Duncan Pritchard (Pritchard, 2012, s. 13). Innej wersji dysjunktywizmu epistemologicznego broni Alan Millar. Od koncepcji McDowella i Pritcharda odróżnia ją podejście Knowledge First, zgodnie z którym wiedza nie redukuje się do prawdziwego uzasadnionego przekonania. Według Millara jest odwrotnie: to wiedza jest źródłem uzasadnienia dla przekonań (Millar, 2010, s. 139-140).

Wspomniane wątpliwości pojawiają się, gdy zapytamy, czy negacja epistemologicznej wersji Zasady Wspólnego Czynnika zobowiązuje do negacji metafizycznej wersji tej zasady. Innymi słowy, czy dysjunktywizm epistemologiczny implikuje dysjunktywizm metafizyczny? W innym artykule argumentuję, że chociaż nie może tu być mowy o logicznej implikacji, to jednak wiarygodność dysjunktywizmu epistemologicznego zależy od wiarygodności dysjunktywizmu metafizycznego, a argumenty przytaczane za tym pierwszym twierdzeniem implicite odwołują się do tego drugiego (Zięba, 2014). Skoro jednak epistemologiczna wersja dysjunktywizmu nie implikuje wersji metafizycznej, to Pritchard i McDowell mają rację, kiedy utrzymują, że dysjunktywizm epistemologiczny jest logicznie spójny z przy-

17 Jest to oczywiście bardzo uproszczony zarys debaty pomiędzy internalizmem a eksternalizmem epistemicznym. Wchodzenie w niuanse tej debaty nie jest tu jednak konieczne. Bardziej szczegółowy opis można znaleźć w książce Jana Woleńskiego (2007, s. 377). 
czynową teorią percepcji (McDowell, 2008, s. 382, przypis 7; Pritchard, 2012, s. 24) ${ }^{18}$.

Millar myśli podobnie: nie musimy przejmować się tym, że percepcyjna relacja o przyczynowym i w efekcie przygodnym charakterze nie zagwarantuje nam poznawczego kontaktu ze światem, ponieważ wyjaśnienie, jak taki kontakt jest możliwy, możemy uzyskać na inne sposoby, na przykład postulując posiadanie przez podmiot tzw. percepcyjno-rozpoznawczych zdolności (Millar, 2007, s. 191-192). Nawet jeśli okaże się, że wybór tej strategii prowadzi w ślepą uliczkę, sama możliwość takiego wyboru świadczy o tym, że negacja epistemologicznej wersji Zasady Wspólnego Czynnika jest logicznie spójna z akceptacją jej metafizycznej wersji.

\section{Konkluzje}

Rozważania niniejsze nie pretendują, rzecz jasna, do roli wyczerpującego opracowania całego spektrum teorii zobowiązanych do dysjunktywizmu, nawet jeśli ograniczymy się do koncepcji bronionych na gruncie filozofii percepcji i epistemologii. Mimo to można z nich wyciągnąć dwa ważne wnioski: (1) wspólny mianownik pomiędzy różnymi wersjami dysjunktywizmu nie może być identyfikowany ze zobowiązaniem do jakiegoś ściśle określonego rozumienia natury percepcyjnej relacji, nawet jeśli mamy dobre powody, aby sądzić, że tylko jedno takie rozumienie czyni dysjunktywizm wiarygodnym; (2) różne wersje dysjunktywizmu dają się w zrozumiały sposób przedstawić bez posługiwania się logicznym funktorem alternatywy (w tym artykule ani razu nie użyłem go w tym celu).

\section{Bibliografia}

Brogaard, B. (2011). Disjunctivism. Oxford Bibliographies Online Research Guide. Oxford: Oxford University Press.

Burge, T. (1991). Vision and Intentional Content. W: E. Lepore, R. van Gulick (eds.), John Searle and His Critics (s. 195-213). Oxford, UK-Cambridge, MA: Blackwell.

18 W kwestii natury doświadczenia percepcyjnego McDowell jest zwolennikiem pewnej wersji wspomnianego już poglądu umiarkowanego (McDowell, 2013a, s. 155-156). 
Burge, T. (2005). Disjunctivism and Perceptual Psychology. Philosophical Topics, $33(1), 1-78$.

Burge, T. (2011). Disjunctivism Again. Philosophical Explorations, 14 (1), 43-80.

Byrne, A., Logue, H. (2008). Either/Or. W: A. Haddock, F. MacPherson (eds.), Disjunctivism: Perception, Action, Knowledge (s. 57-94). Oxford: Oxford University Press.

Byrne, A., Logue, H. (2009). Introduction. W: A. Byrne, H. Logue (eds.), Disjunctivism: contemporary readings (s. VII-XXIX). Cambridge: MIT Press.

Campbell, J. (2002). Reference and Consciousness. Oxford: Oxford University Press.

Chalmers, D. (2010). Świadomy umyst. W poszukiwaniu teorii fundamentalnej. Tłum. M. Miłkowski. Warszawa: Wydawnictwo Naukowe PWN.

Conduct, M.D. (2010). Naïve realism and extreme disjunctivism. Philosophical Explorations, 13 (3), 201-221.

Crane, T. (2006). Is there a perceptual relation? W: T. Gendler, J. Hawthorne (eds.), Perceptual Experience (s. 126-146). Oxford: Oxford University Press.

Crane, T. (2011). The Problem of Perception. W: E.N. Zalta (ed.), The Stanford Encyclopedia of Philosophy (Spring 2011 Edition). Pobrane z: http://plato. stanford.edu/archives/spr2011/entries/perception-problem/.

Dretske, F. (2000). The Mind's Awareness of Itself. W: Perception, Knowledge and Belief. Selected Essays (s. 158-177). Cambridge University Press.

Fish, W. (2010). Philosophy of Perception. A Contemporary Introduction. Oxford, UK-Cambridge, MA: Routledge.

Haddock, A., MacPherson, F. (2008). Introduction. Varieties of disjunctivism. W: A. Haddock, F. MacPherson (eds.), Disjunctivism: Perception, Action, Knowledge (s. 1-24). Oxford: Oxford University Press.

Hellie, B. (2014). The Multidisjunctive Conception of Hallucination. W: F. MacPherson, D. Platchias (eds.), Hallucination. Philosophy and Psychology (s. 149-173). Cambridge, London: MIT Press.

Hinton, J.M. (2009a). Selections from Experiences. W: A. Byrne, H. Logue (eds.), Disjunctivism: contemporary readings (s. 13-32). Cambridge: MIT Press.

Hinton, J.M. (2009b). Visual Experiences. W: A. Byrne, H. Logue (eds.), Disjunctivism: contemporary readings (s. 1-11). Cambridge: MIT Press. 
Johnston, M. (2009). The obscure object of hallucination. W: A. Byrne, H. Logue (eds.), Disjunctivism: contemporary readings (s. 207-269). Cambridge: MIT Press.

MacPherson, F. (2014). The Philosophy and Psychology of Hallucination: An Introduction. W: F. MacPherson, D. Platchias (eds.), Hallucination. Philosophy and Psychology (s. 1-38). Cambridge, London: MIT Press.

Madison, B.J.C. (2010). Epistemic Internalism. Philosophy Compass, 5 (10), 840-853.

Martin, M.G.F. (2002). The Transparency of Experience. Mind and Language, $4(4), 376-425$.

Martin, M.G.F. (2006). On Being Alienated. W: T. Gendler, J. Hawthorne (eds.), Perceptual Experience (s. 354-410). Oxford: Oxford University Press.

Martin, M.G.F. (2009a). The Limits of Self-Awareness. W: A. Byrne, H. Logue (eds.), Disjunctivism: contemporary readings (s. 271-318). Cambridge: MIT Press.

Martin, M.G.F. (2009b). The Reality of Appearances. W: A. Byrne, H. Logue (eds.), Disjunctivism: contemporary readings (s. 91-116). Cambridge: MIT Press.

McDowell, J. (1998). Criteria, defeasibility and knowledge. W: J. McDowell (ed.), Meaning, Knowledge and Reality (s. 369-394). Cambridge, MA: Harvard University Press.

McDowell, J. (2008). The Disjunctive Conception of Experience as Material for a Transcendental Argument. W: A. Haddock, F. MacPherson (eds.), Disjunctivism: Perception, Action, Knowledge (s. 376-389). Oxford: Oxford University Press.

McDowell, J. (2010). Tyler Burge on disjunctivism. Philosophical Explorations, 13 (3), 243-255.

McDowell, J. (2013a). Perceptual Experience: Both Relational and Contentful. European Journal of Philosophy, 21 (1), 144-157.

McDowell, J. (2013b). Tyler Burge on disjunctivism (II). Philosophical Explorations, 16 (3), 259-279.

Millar, A. (2007). What the Disjunctivist is Right About. Philosophy and Phenomenological Research, 74 (1), 176-198.

Millar, A. (2010). Knowledge and Recognition. W: D. Pritchard, A. Millar, A. Haddock (eds.), The Nature and Value of Knowledge. Three Investigations. Oxford: Oxford University Press. 
Phillips, I. (b.d.w.). Uncoscious Perception Reconsidered. Pobrane z: http://www. ianbphillips.com/uploads/2/2/9/4/22946642/antwerp.pdf.

Pritchard, D. (2012). Epistemological Disjunctivism. Oxford: Oxford University Press.

Pryor, J. (2001). Highlights of Recent Epistemology. British Journal for the Philosophy of Science, 52, 95-124.

Schellenberg, S. (2014). The Relational and Representational Character of Perceptual Experience. W: B. Brogaard (ed.), Does Perception have Content? (s. 199-220). Oxford: Oxford University Press.

Schetz, A. (2007). Alternatywizm w teorii percepcji. Diametros, 14, 85-104.

Schetz, A. (2014). Biologiczny eksternalizm w teoriach percepcji. Szczecin: Wydawnictwo Naukowe Uniwersytetu Szczecińskiego.

Siegel, S. (2010). The Contents of Visual Experience. New York: Oxford University Press.

Snowdon, P. (2008). Hinton and the Origins of Disjunctivism. W: A. Haddock, F. MacPherson (eds.), Disjunctivism: Perception, Action, Knowledge (s. 35-56). Oxford: Oxford University Press.

Snowdon, P. (2009a). Perception, Vision, and Causation. W: A. Byrne, H. Logue (eds.), Disjunctivism: contemporary readings (s. 33-48). Cambridge: MIT Press.

Snowdon, P. (2009b). The Objects of Perceptual Experience. W: A. Byrne, H. Logue (eds.), Disjunctivism: contemporary readings (s. 49-74). Cambridge: MIT Press.

Soteriou, M. (2000). The Particularity of Visual Perception. European Journal of Philosophy, 8 (2), 173-189.

Soteriou, M. (2005). The Subjective View of Experience and Its Objective Commitments. Proceedings of the Aristotelian Society, New Series, 105, 177-190.

Soteriou, M. (2010a). Perceiving Events. Philosophical Explorations, 13 (3), 223-241.

Soteriou, M. (2010b). The Disjunctive Theory of Perception. W: E.N. Zalta (ed.), The Stanford Encyclopedia of Philosophy (Winter 2010 Edition). Pobrane z: http://plato.stanford.edu/archives/win2010/entries/perception-disjunctive/.

Thau, M. (2004). What is Disjunctivism? Philosophical Studies, 120 (1), 193-253. 
Travis, C. (2013). Frege, Father of Disjunctivism. W: Perception. Essays After Frege (s. 59-89). Oxford: Oxford University Press.

Tye, M. (2007). Intentionalism and the argument from no common content. Nô̂s, 41 (1), 589-613.

Tye, M. (2014). What is the content of a hallucinatory experience? W: B. Brogaard (ed.), Does Perception have Content? (s. 291-310). New York: Oxford University Press.

Woleński, J. (2007). Epistemologia. Poznanie, prawda, wiedza, realizm. Warszawa: Wydawnictwo Naukowe PWN.

Zięba, P.J. (2014). In Search of the Holy Grail of Epistemology. Kriterion - Journal of Philosophy, 28, 55-74.

\section{DISJUNCTIVISM AND THE NATURE OF PERCEPTUAL RELATION}

\section{Summary}

This paper surveys selected (though arguably representative) versions of metaphysical and epistemological disjunctivism. Although they share a common logical structure, it is hard to find a further common denominator among them. Two main conclusions are: (1) a specific standpoint on the nature of perceptual relation is not such a common denominator, which means that it is very unlikely that all of these views could be refuted with a single objection; (2) contrary to what its name suggests, disjunctivism can be correctly expressed without the employment of disjunction. 